information available for future use. With informed consent samples from the birth parents could be stored for the future benefit of the adopted person. This may obviate the need to trace the birth parents if genetic disease emerges later. Registering the storage of DNA would need to be centralised and access to it safeguarded by legislation but these are not insurmountable problems.

(5) Lastly, record keeping and tracing. Even if much of the above were considered desirable there will be instances where progress can only be made by finding one or more key individuals in the biological family. The quality of record keeping may be tested under these circumstances and raise the issue of devising better ways of tracing people's movements through life. However, proposals to improve such tracing are likely to provoke opposition as infringements of personal freedom.

We are left with no final solution to the questions of 'rights' and 'confidentiality of information' with respect to genetic medical history and DNA. Adoption is an example of a process where there is particular need for discussion and debate about the special moral and legal issues raised by molecular genetic techniques. It is an issue that will have repercussions world wide wherever the adoption of children by non-relatives is practised and legalised. In the meantime the legal framework in the UK is inadequate and there is no consensus about how to proceed when genetic disease emerges after an adoption placement. There is a clear need for an examination of this whole issue and a broad based debate about how these conflicts of interest can be acknowledged and resolved.

PETER D TURNPENNY SHEILA A SIMPSON

Department of Medical Genetics,

Medical School,

Foresterhill,

Aberdeen $A B 9$ 2ZD

Department of Social Work,

University of Dundee,

Dundee DD1 4 HN

1 Report of the committee on the ethics of gene therapy. HMSO: London, January 1992: 15-6.

2 Pelias MZ. Duty to disclose in medical genetics: a legal perspective. Am $\mathcal{f}$ Med Genet 1991; 39: 347-54

3 Carter CO, BAAF Working Party. In: Oxtoby M, ed. Genetics in adoption and fostering. London: British Agencies for Adoption and Fostering, 1982.

4 Morris M, Tyler A, Harper PS. Adoption and genetic prediction for Huntington's disease. Lancet 1988; 332: 1069.

5 Adoption of Children (Scotland) Act 1930.

6 Children Act 1975. Section 26: obtaining of birth certificate by adopted person.

7 McWhinnie AM. Adopted children. How they grow up. London: Routledge and Kegan Paul, 1967.

8 Schechter MD, Bertocci D. The meaning of the search. In: Brodzinsky DM, Schechter MD, eds. The psychology of adoption. Oxford: Oxford University Press, 1990

9 Hoksbergen RAC, Gokhale SD. Adoption in worldwide perspective. Lisse: Swets and Zeitlinger BV, 1986.

10 Registrar General for Scotland. Annual report of the registrar general for Scotland 1990. Edinburgh: General Register Office, 1991: 142.

11 Baird PA, Anderson TW, Newcombe HB, Lowry RB. Genetic disorders in children and young adults: a population study. Am $\mathfrak{f}$ Hum Genet 1988; 42: children

12 Bodmer W. Hands off the human gene! Guardian 3 April, 1992: 19

13 Harper PS, Clarke A. Should we test children for 'adult' genetic disease? Lancet 1990; 335: 1205-7.

\title{
Iatrogenic deaths in hereditary fructose intolerance
}

The rarity of a disease provides little reassurance for those who suffer from it. Hereditary fructose intolerance (HFI) was described more than 35 years ago $^{1}$ but fatal cases (sometimes related to the medicinal use of fructose based intravenous solutions) continue to occur. Given that the disorder responds to dietary treatment and is compatible with a normal duration of life,${ }^{2}$ how do these tragedies arise?

Best known to paediatricians, HFI characteristically presents with vomiting, symptomatic hypoglycaemia, and failure to thrive during weaning or on transfer from breast milk to fruit juice or artificially sweetened feeds. The affected infant has feeding difficulties and episodes of disturbed consciousness or even hypoglycaemic seizures occur. Should administration of fructose, or the related sugars sucrose or sorbitol continue, chronic intoxication results: there is jaundice, liver enlargement, renal tubular dysfunction, and a haemorrhagic tendency accompanying hepatic failure that leads to death..$^{2-4}$

The abundance of sucrose and fructose in infant foods renders survival dependent on significant reductions of sugar intake: the mother may identify preparations that provoke symptoms or the infant itself develops an aversion to sweet tasting foods and drinks. Avoidance of sweet comestibles was noted by Chambers and Pratt who, first reporting 'idiosyncrasy to fructose' in a 24 year old woman, observed that she could take glucose without ill effect but did not enjoy the taste. ${ }^{\prime}$ Before diagnosis, most adults with HFI ingest only a few grams of fructose or sucrose per day - a fraction of that consumed by healthy individuals - and dental caries is rare. ${ }^{5}$
None the less, they continue to suffer abdominal symptoms and hypoglycaemia intermittently as a result of accidental dietary indiscretions. Although chronic intoxication with fructose has been considered unlikely after institution of a restricted diet, rigorous studies in children with HFI show that growth retardation accompanied by biochemical abnormalities occurs unless dietary fructose is reduced to less than $40 \mathrm{mg}$ per kilogram body weight per day. ${ }^{6}$

HFI is transmitted as an autosomal recessive trait with an estimated frequency of one in 20000 live births. ${ }^{7}$ The disease is caused by genetic defects in the specialised enzyme of fructose metabolism, aldolase $\mathrm{B} .^{8}$ Aldolase $\mathrm{B}$ is expressed in the liver, small intestine, and proximal renal tubule where it ${ }^{\circ}$ facilitates assimilation of dietary fructose by catalysing the cleavage of fructose-1-phosphate. ${ }^{9}$ In the absence of fructose - either ingested as the free sugar or derived from sucrose or sorbitol - patients with HFI suffer no ill effects but exposure to small amounts of this sugar induces functional impairment, for example renal tubular acidosis, ${ }^{10}$ and eventually structural injury in the tissues that are sites for its metabolism.

The mechanisms of fructose toxicity are complex: intracellular sequestration of fructose-1-phosphate depletes the intracellular pool of free inorganic phosphate (as shown by ${ }^{31} \mathrm{P}$ magnetic resonance spectroscopy in vivo ${ }^{11}$ and these effects inhibit glycogenolysis and gluconeogenesis leading to refractory hypoglycaemia. ${ }^{212}$ Feedback inhibition of ketohexokinase reduces the further metabolism of fructose so that when the renal threshold is exceeded this reducing sugar 
appears in the urine: fructosaemia is an obsolete term for this disorder. Hyperuricaemia and hypermagnesaemia result from degradation of adenine nucleotides within the liver and reflect activation of adenosine deaminase by reduced intracellular concentrations of free inorganic phosphate. ${ }^{13}$ Breakdown of nucleotides that exist as preformed magnesium ion complexes causes loss of energy charge and critically impairs cellular metabolism. The cause of tissue injury resulting from continued exposure to fructose in HFI is unknown but acute experimental challenge induces ultrastructural changes in the liver and jejunum. ${ }^{14}$ The appearance of amorphous deposits and concentric membraneous arrays suggests that autophagocytosis with lysosomal accumulation of fructose-1phosphate may contribute.

Parenteral administration of fructose based solutions, including invert sugar and sorbitol (that is rapidly converted to fructose by sorbitol dehydrogenase in the liver), to patients with HFI causes acute liver cell necrosis and profound metabolic acidosis. ${ }^{15-17}$ At least 15 fatal cases with irreversible hepatorenal failure have been reported from several countries and many others are known. ${ }^{38-20}$ Once popular as a nutrient in postoperative intravenous fluids, for children and for parenteral hyperalimentation, the use of fructose in most countries has declined markedly since the late 1970s. However, in continental Europe, especially in German speaking countries, sorbitol or fructose solutions are routinely administered during surgery. ${ }^{18}$ In the last decade, all instances of severe poisoning with fructose and iatrogenic death in HFI have been reported from Germany or Austria. The correlation between prescribing practice and outcome is striking: it should convince complacent paediatricians and physicians elsewhere that HFI is not over represented in Germany, Switzerland, or Austria. Given also that these tragic accidents occur in older children and adults, the conclusion that many patients with HFI survive infancy and, as a result of self imposed dietary restriction, live to adulthood eluding formal diagnosis, appears to be inescapable.

The emergence of sucrose as a commodity as well as a major constituent of Western style diets has its roots in the colonial and industrial history of cane sugar and, later, beet sugar. ${ }^{21}$ In contrast, the rise of fructose as a fashionable nutrient for medicinal use has been short lived. Feeding experiments by Minkowski in the last century showed that fructose could be assimilated rapidly after pancreatectomy ${ }^{22}$ and Külz in 1874 showed that this sugar was preferentially metabolised by patients with diabetes mellitus. That fructose uptake by the liver was independent of insulin, and that this sugar (less irritant to the veins than equally concentrated solutions of glucose) was more rapidly utilised, were further theoretical advantages. Studies showing that fructose has less effect on blood sugar concentrations in postoperative patients and diabetic subjects than equivalent amounts of glucose, led to its widespread use as a parenteral nutrient. Fructose and its precursor, sorbitol, have been advocated for the treatment of diabetic ketoacidosis ${ }^{23}$ for parenteral nutrition in adults ${ }^{24}$ and, in the form of invert sugar, for children. ${ }^{25}$ Later, hyperuricaemia reflecting nucleotide degradation ${ }^{26}$ and severe lactic acidosis ${ }^{27}$ resulting from infusion of fructose in patients without HFI were documented; many authors have warned of its dangers - especially in the critically ill. ${ }^{28} 29$ In most countries these warnings have been heeded and although fructose and sorbitol are still used as sweeteners and sugar substitutes in diabetic foods, parenteral preparations have fallen from favour.

HFI provides a vivid example of how genetic and dietary factors, modified by eating behaviour, interact to cause disease. Molecular analysis of aldolase $B$ genes from patients with HFI originating from many countries has shown that a few point mutations account for more than $85 \%$ of defective alleles. ${ }^{30}$ Well over one half of these disease alleles are accounted for by one mutation that is readily detected and widely distributed. ${ }^{30-32}$ Until now, no simple test for the diagnosis of HFI has been available: diagnosis has relied on the intravenous fructose tolerance test or enzymatic assay of fructaldolase activities in liver tissue intestinal mucosa obtained by biopsy. ${ }^{3}$ Latterly, the use of mutation specific oligonucleotide probes has facilitated diagnosis of HFI in individuals with symptoms by direct analysis of DNA amplified in the polymerase chain reaction (PCR). ${ }^{33}$

PCR based methods of DNA analysis for forensic diagnosis are now well established. A recent report of investigations after the unexpected death of an Italian girl after appendicectomy confirms their power. ${ }^{34}$ The patient, who like a surviving brother, had had a life long distaste for fruit and sweetmeats, was treated in Germany, where she received intravenous sorbitol and fructose during and after surgery. She died as a result of acute hepatorenal failure. Sequence analysis of DNA from the brother identified two unusual mutations giving rise to null alleles of aldolase B. Molecular analysis of DNA obtained from a fragment of necrotic liver that had been obtained postmortem by needle aspiration, fixed and embedded for histological examination, confirmed the presence of both mutations and the cause of death.

The lethal effects of parenteral fructose in patients with HFI at all ages are well recognised but indiscriminate use of fructose based solutions in patients with dietary intolerance of this sugar, though often recorded, is surely indefensible. In countries where traditional prescribing practices and commercial influences promote the routine administration of fructose, there is a clear duty (as with the avoidance of repeated halothane use) to take a history first. Several instances of parent-to-offspring transmission of HRI (a recessive disease) indicate that mutant alleles of aldolase $B$ occur with an appreciable frequency in the population..$^{35}$ Fructose intolerance resembles phenylketonuria: it occurs with similar frequency and responds completely to appropriate dietary treatment. For these reasons, population screening for HFI before weaning may be justified as the most common mutations can be easily detected by PCR based methods. Pilot studies to determine the usefulness of screening could be based on population archives in the form of the Guthrie blood spot provide unbiased samples of DNA. Sweeter fruits to come from the application of molecular genetics?

TIMOTHY M COX

Department of Medicine,

University of Cambridge,

Addenbrooke's Hospital,

Hills Road,

Cambridge CB2 $2 Q Q$

1 Chambers RA, Pratt RTC. Idiosyncrasy to fructose. Lancet 1956; ii: 340.

2 Gitzelmann R, Steinmann B, Van den Berghe G. Disorders of fructose metabolism. In: Scriver CR, Beaudet AL, Sly WS, Valle D, eds. The metabolic basis of inherited disease. 6th Ed. New York: McGraw-Hill, 1989. 399-424.

3 Odièvre M, Gertil C, Gautier M, Alagille D. Hereditary fructose intolerance in childhood. Diagnosis, management and course in 55 patients. Am $\mathcal{F}$ Dis Child 1978; 132: 605-8.

4 Baerlocher K, Gitzelmann R, Steinmann B, Gitzelmann-Cumarasamy N. Hereditary fructose intolerance in early childhood: a major diagnostic Hereditary fructose intolerance in early childhood:

challenge. Helvetica Paediatrica Acta 1978; $33: 465-87$. eight patients. Br Dent $\mathcal{F}$ 1967; 123: 597-9.

6 Mock DM, Perman JA, Thaler M, Morris JC. Chronic fructose intoxication after infancy in children with hereditary fructose intolerance. A cause of growth retardation. N Engl F Med 1988; 309; 764-70.

7 Gitzelmann R, Baerlocher K. Vorteile und Nachteile der Fructose in der Nahrung. Pädiatrie Fortbildiung Praxis 1973; 37: 40-55.

8 Hers H-G, Joassin G. Anomalie de l'aldolase hépatique dans l'intolerance au fructose. Enrymology in Clinical Chemistry 1961; 1: 4-14.

9 Hers H-G. Le metabolisme du fructose. Brussels: Editions Arsica, 1957.

10 Morris RC. An experimental renal acidification defect in patients with hereditary fructose intolerance II. $\mathcal{F}$ Clin Invest 1968; 47: 1648-63.

11 Oberhaensli RD, Rajagopalan B, Taylor DJ, Leonard JV, Radda GK. Studies of hereditary fructose intolerance by use of ${ }^{31} \mathbf{P}$ magnetic resonance spectroscopy. Lancet 1987; ii: $931-4$.

12 Dubois R, Loeb H, Ooms HA, Gillet P, Bartman J, Champenois A. Etude d'un case d'hypoglucémie fonctionelle par intolérance au fructose. Helvetica Paediatrica Acta 1961; 16: $90-6$. 
13 Levin B, Snodgrass GJAI, Oberholzer VG, Burgess EA, Dobbs RH Fructosaemia. Observations on seven cases. Am ₹ Med 1968; 45: 825-38.

14 Phillips MJ, Little JA, Ptak TW. Subcellular pathology of hereditary fructose intolerance. Am $\mathcal{F}$ Med 1968; 44: 910-21.

15 Odièvre $M$. Les difficultés du diagnostic de l'intolérance héréditaire au fructose chez le nourrisson. Arch Fr Pédiatr 1969; 26: 5-19.

16 Von Hein W, Schill H, Tessmann D, Kupatz H. Letale heberdystrophie bei drei Geschwistein mit hereditärer Fructoseintoleranz nach Dauertropfinfusionen mit sorbitolhalitgen Infusionslösungen. Deutsche Gesundheitswesen 1969; 24: 2325-9.

17 De Vroede M, Mozin M-J, Cadranel S, Loeb H, Heinmann R. Découverte d'une fructosémie à l'occasion d'une insuffisance hépatique aigue chez un enfant de 16 mois. Pédiatrie 1980; 35: 353-8.

18 Wagner $\mathrm{K}$, Wolf AS. Todesfall nach Fructose-und Sorbitinfusionen. Anaesthesist 1984; 33: 573-8,

19 Hackl JM, Balogh D, Kunz F, Dworzak E, Puschendorf B. Postoperative Fructoseinfusion bei wahrscheinlich hereditärer Fructoseintoleranz. Wien Klin Wochenschr 1978; 90: 237-40.

20 Danks DM, Connellan JM, Solomon JR. Hereditary fructose intolerance: report of a case and comments on the hazards of fructose infusion. Australian Paediatric Fournal 1972; 8: 282-6.

21 Hugill A. Sugar and all that. London: Gentry Books, 1978.

22 Minkowski O. Untersuchungen uber den Diabetes mellitus nach Extirpation des Pankreas. Naunyn-Schmiedebergs Archiv für Experimentelle Pathologie and Pharmacologie 1893; 31: 85-189.

23 Darragh JH, Womersley RA, Meroney WH. Fructose in the treatment of diabetic ketosis. F Clin Invest 1953; 32: 1214-21.

24 Allen PC, Lee HA. A guide to intravenous nutrition. London: Oxford University Press, 1969: 27.
25 Lane HC, Dodd K. Use of gluctose, invert sugar and fructose for parenteral feeding of children. Pediatrics 1953; 20: 668-75.

26 Perheentupa J, Raivio K. Fructose-induced hyperuricaemia. Lancet 1968; ii: 528-31.

27 Bergström J, Hultman E, Roch-Norlund AE. Lactic acid accumulation in connection with fructose infusion. Acta Medica Scandinavica 1972; 184: 35964.

28 Lameire N, Mussche M, Baele G, Kint J, Ringoir S. Hereditary fructose intolerance: a difficult diagnosis in the adult. Am F Med 1978; 65: 416-23.

29 Woods HF, Alberti KGMM. Dangers of intravenous fructose. Lancet 1977; ii: $1354-7$.

30 Cross NCP, De Franchis R, Sebastio G, et al. Molecular analysis of aldolase B genes in hereditary fructose intolerance. Lancet 1990; 335: 306-9.

31 Cross NCP, Tolan DR, Cox TM. Catalytic deficiency of human aldolase B in hereditary fructose intolerance caused by a common missense mutation. Cell 1988; 53: 881-5.

32 Cross NCP, Cox TM. Molecular analysis of aldolase B genes in the diagnosis of hereditary fructose intolerance in the United Kingdom. Quart 7 Med 1989; 73: $1015-20$.

33 Cox TM. Fructose intolerance: heredity and the environment. In: Randle PJ, Bell J, Scott J, eds. Genetics and human nutrition. London: John Libby, 1990: 81-92.

34 Ali M, Rosien U, Cox TM. DNA diagnosis of fatal fructose intolerance from achival tissue. Quart $\mathcal{f}$ Med 1993; 86: 25-30.

35 Cox TM, Camilleri M, O'Donnell MW, Chadwick VS. Pseudodominant transmission of fructose intolerance in an adult and three offspring. transmission of fructose intolerance in an adult and three offspring.
Heterozygote detection by intestinal biopsy. NEnglf Med 1982;307:537-40. 